\section{PENINGKATAN KETERAMPILAN PRAKTIK INSTRUMEN PERKUSI MAHASISWA MELALUI PENGGUNAAN PORTOFOLIO}

\section{Herwin Yogo Wicaksono dan Ayu Niza Machfauzia}

Fakultas Bahasa dan Seni Universitas Negeri Yogyakarta

\section{Abstract}

This study aims to find out about (a) the use of portofolios in Percussion Music Instrument practical course, (b) to find out what can be done to improve students' ability in learning to play this instrument. This research is an action research conducted in Music education Department, Yogyakarta State University. The subjects of this research are the students of semester I and semester III who take PIM Percussion course. The data were collected through a competence test, interviews, and observation. The data analysis technique was conducted by applying the quantitative descriptive analysis method which enables the researcher to present quantitative data, and qualitative descriptive method used to describe the data from observations and interviews. The research results show that through the use of portofolios, the students' abilities to practice to play this instrument are significantly improved in terms of psychomotor, cognitive, and affective skills. This is proven with the average score gained by students of semester I, which is about 64.25 in Cycle I and 73.25 in Cycle II, and the average score gained by the students of Semester III, which is about 68 in Cycle I and 74.5 in Cycle II.

Keywords: portofolio, ability, instrument practice, percussion

\section{PENDAHULUAN}

Jurusan Pendidikan Musik FBS UNY merupakan salah satu lembaga pendidikan formal yang menyelenggarakan berbagai mata kuliah yang berkaitan dengan musik baik teori maupun praktik. Penyelenggaraan perkuliahan tersebut dilaksanakan seperti pada umumnya yaitu bersifat klasikal (untuk setiap mata kuliah teori), dan bersifat kelompok untuk mata kuliah praktik instrumen, yang masing-masing kelompok rata-rata terdiri atas $3-10$ orang mahasiswa dengan 1 orang dosen. Bahkan untuk instrumen tertentu (seperti gitar), jumlah mahasiswa dalam tiap kelompoknya 10-25 orang dengan 1 orang dosen. Tentu saja kondisi pembelajaran seperti ini sangat tidak efektif.

Sistem pelaksanaan perkuliahan praktik instrumen tersebut dirasa memiliki kelemahan, sehingga dalam pelaksanaannya kurang dapat memperoleh hasil yang maksimal. Hal ini nampak dari hasil perkuliahan yang telah diperoleh selama ini, yaitu kurang maksimalnya keterampilan mahasiswa dalam bermain instrumen. Adapun kelemahan tersebut antara lain disebabkan oleh sulitnya memantau perkembangan tiap-tiap mahasiswa dalam belajar praktik instrumen, dan alokasi waktu yang dibutuhkan pada tiap tatap muka sangat terbatas. Demikian pula halnya dengan pelaksanaan perkuliahan praktik instrumen Perkusi.

Dalam pelaksanaan perkuliahan praktik instrumen Perkusi yang telah berjalan selama ini, mahasiswa dibagi menjadi dua kelas yaitu kelas Reguler dan kelas Non Reguler. Jumlah mahasiswa tiap kelompok rata-rata $3-6$ orang bahkan pada kelompok tertentu ada yang sampai 8 orang. Tentu saja hal ini merupakan kondisi yang kurang kondusif. Padahal, untuk mencapai hasil yang optimal, jumlah mahasiswa yang mengikuti kuliah praktik instrumen Perkusi idealnya 1-2 orang dengan 1 orang dosen.

Pada kenyataan yang terjadi di lapangan, khususnya pada kelas Reguler, jumlah mahasiswa semester I yang mengikuti perkuliahan Praktik Individual Mayor (PIM) Perkusi sebanyak 2 orang, dan ini sebenarnya sudah dapat dikatakan ideal. Sedangkan jumlah mahasiswa semester III yang mengikuti perkuliahan tersebut sebanyak 3 orang. Namun, pada pelaksanaannya masih banyak ditemui kendala-kendala.

Perkuliahan praktik instrumen Perkusi memiliki tujuan agar mahasiswa memahami dan menguasai teknik-teknik dasar dalam bermain perkusi baik ritmis maupun melodis. Tidak hanya menguasai teknik-teknik tersebut, tetapi juga dapat menginterpretasikan dengan baik setiap ritme dan melodi yang dimainkan. Untuk mencapai tujuan tersebut diperlukan pengetahuan awal berupa teori, konsep dan berbagai hal mengenai permainan instrumen Perkusi. Dengan harapan mahasiswa akan mampu menggunakan berbagai pengetahuan dan kemampuannya tersebut untuk mengaplikasikan dalam kehidupan berkesenian di masyarakat kelak.

Namun, selain permasalahan yang telah diuraikan tersebut, terdapat pula beberapa gejala yang merupakan indikasi adanya kesulitan dalam kegiatan belajar khususnya belajar praktik instrumen Perkusi yang timbul dari dalam diri mahasiswa itu sendiri, antara lain: 1) Sebagian besar mahasiswa pasif dalam mengikuti perkuliahan; 2) Mahasiswa kelihatan kurang mandiri dan kurang bersemangat; 3) Mahasiswa tidak dapat menyelesaikan tugas-tugas berupa latihan-latihan yang diberikan dengan baik; 4) Kurangnya motivasi mahasiswa dalam belajar; 5) Tidak dapat membagi waktu untuk latihan. 
Dari wawancara dengan mahasiswa yang menempuh mata kuliah PIM Perkusi, yang dilaksanakan pada 17 dan 20 September 2007, terungkap bahwa mahasiswa merasa keberatan karena harus belajar instrumen Perkusi lebih dari satu alat. Artinya, setiap mahasiswa yang mempelajari instrumen Perkusi harus mempelajari instrumen Perkusi baik ritmis maupun melodis, yang dalam hal ini Drum dan Timpani untuk Perkusi ritmis, serta Marimba untuk instrumen Perkusi melodis. Namun, bagi mahasiswa semester I, hanya mempelajari Drum dan Marimba saja. Hal ini dikarenakan mahasiswa semester I perlu memahami dengan baik dan benar teknik-teknik dasar bermain instrumen Perkusi, dan memiliki kemampuan membaca notasi balok dengan baik terlebih dahulu.

Sementara itu, mahasiswa semester III mempelajari ketiga instrumen Perkusi tersebut, karena di samping sudah memiliki kemampuan membaca notasi balok, juga sudah memahami dan mengerti teknik-teknik dasar bermain instrumen Perkusi. Dengan adanya beberapa instrumen Perkusi yang harus dipelajari, tidak sedikit mahasiswa yang memiliki motivasi rendah dan merasa kesulitan untuk belajar instrumen Perkusi. Untuk mengatasi permasalahan yang muncul, ada berbagai macam cara yang dapat dilakukan agar hasil yang diperoleh dalam belajar praktik instrumen khususnya Perkusi dapat optimal

Dalam penelitian ini salah satu cara yang digunakan untuk meningkatkan keterampilan bermain instrumen Perkusi adalah dengan memanfaatkan portofolio, yaitu mencatat dan merekam secara detail hasil praktik mahasiswa dalam bermain instrumen Perkusi. Dengan memanfaatkan portofolio tersebut diharapkan dapa mengetahui dan memantau perkembangan dari tiap mahasiswa secara lebih rinci Selain itu, dapat meningkatkan motivasi dan prestasi mahasiswa dalam belajar praktik instrumen Perkusi.

Berdasarkan hal-hal yang telah diuraikan tersebut, maka dapa dirumuskan permasalahan sebagai berikut: 1) Bagaimanakah penggunaan portofolio dalam kuliah praktik instrumen Perkusi?; 2) Upaya apakah yang dapat digunakan untuk meningkatkan keterampilan mahasiswa dalam belajar praktik instrumen Perkusi?

Sesuai dengan permasalahan penelitian yang dikemukakan tersebut, maka tujuan penelitian ini adalah 1) mengetahui penggunaan portofolio dalam kuliah praktik instrumen Perkusi; 2) mengetahui upaya yang dapat digunakan untuk meningkatkan keterampilan mahasiswa dalam belajar praktik instrumen Perkusi.

Melalui penelitian ini diharapkan dapat memberikan hasil sebagai berikut: 1) memberikan sumbangan teoritis dalam pemanfataan portofolio dalam praktik instrumen khususnya instrumen Perkusi; 2) Secara praktis, bagi dosen maupun para pendidik di bidang musik, hasil penelitian ini dapat memberikan masukan tentang penggunaan portofolio khususnya pada pembelajaran praktik instrumen.
Tujuan dari penggunaan portofolio adalah untuk menentukan kejadiankejadian serta perkembangan-perkembangan yang terjadi dalam proses belajar mengajar. Adapun portofolio yang digunakan dapat berisi berbagai macam item, antara lain seperti graded assignments, papers, dan self reflection pieces (Sharp, 1997 : 3). Dalam praktik instrumen Perkusi, sebagai contoh portofolio dapat berisi antara lain penilaian diri mahasiswa dalam berlatih teknik pukulan yang dicatat dan direkam. Dengan demikian, kelemahan-kelemahan mahasiswa saat berlatih teknik pukulan dapat terdeteksi, sehingga untuk selanjutnya dapat diperbaiki.

Penggunaan portofolio dapat dilakukan pada setiap akhir semester. Selain itu, dapat pula digunakan pada setiap akhir materi pembelajaran selesai diberikan (Sharp, 1997 : 1). Portofolio ini juga dapat digunakan untuk mengesahkan sebuah kompetensi kenaikan tingkat. Hal ini seperti yang diutarakan Sharp (1997 : 3) berikut ini." the portfolio is sometimes used to certify competence to move to the next level". Dengan demikian, sebagian besar portofolio digunakan pada dua kategori pokok, yaitu penilaian dan pengajaran.

Hal senada dikatakan oleh Mangkoesapoetra (2007 : 4) bahwa sebagai adjective, portofolio pada umumnya disandingkan dengan konsep pembelajaran yang dikenal dengan istilah pembelajaran berbasis portofolio (portfolio based learning) dan dapat disandingkan dengan konsep penilaian yang dikenal dengan istilah penilaian berbasis portofolio (portfolio based assessment). Selanjutnya menurut Mangkoespoetra (2007 : 5) bahwa portofolio dapat diartikan sebagai suatu wujud benda fisik berupa bundel, yakni kumpulan atau dokumentasi hasil pekerjaan peserta didik yang disimpan pada suatu bundel, antara lain seperti hasil tes awal (pretest), tugas-tugas, catatan-catatan dalam mengikuti pembelajaran, keterangan melaksanakan tugas terstruktur, dan hasil tes akhir (post-test). Selain itu, portofolio dapat juga diartikan sebagai suatu proses sosial pedadogis, yaitu collection of learning experience yang terdapat di dalam pikiran peserta didik baik yang berujud pengetahuan (kognitif), keterampilan (skill), maupun nilai dan sikap (afektif).

Dalam penelitian ini, portofolio yang dimaksud adalah berupa lembaran catatan tentang kemajuan mahasiswa dalam mengikuti proses pembelajaran, yang meliputi pengetahuan (kognitif), serta nilai dan sikap (afektif). Sementara itu, aspek keterampilan (skill) dikemas dalam CD yang berisi rekaman mahasiswa dalam memainkan instrumen Perkusi. Dengan penggunaan portofolio dalam pembelajaran praktik instrumen Perkusi, selain diupayakan dapat membangkitkan minat belajar siswa secara aktif, kreatif, juga dapat mengembangkan pemahaman nilai-nilai kemampuan berpartisipasi secara efektif, serta diiringi suatu sikap tanggung jawab.

Instrumen Perkusi merupakan alat musik yang cara memainkannya dipukul dengan alat dan terbagi dalam dua jenis yaitu ritmis, dan melodis. 
Dikatakan melodis karena instrumen ini memiliki nada-nada, dan nada itu sendiri adalah bunyi yang memiliki frekuensi teratur dan dapat dibedakan antara nada yang satu dengan nada lainnya, contoh nada a yang memiliki frekuensi $440 \mathrm{~Hz}$, sebagaimana yang dikemukakan oleh Jones (1974:3) berikut ini: "Irregular and complex vibrations are usually classified as noise, while reguler vibrations produce tones of a discernible pitch".

Pada dasarnya, teknik memainkan instrumen Perkusi khususnya Perkusi melodis hampir sama, yaitu dengan cara dipukul bergantian antara tangan kanan dan kiri. Menurut Diagram (1976: 227), ada delapan teknik memainkan instrumen Perkusi, yaitu: 1) Stamping; 2) Stamped; 3) Shaken; 4) Concussion; 5) Percussion, 6) Friction; 7) Scraped; 8) Plucked

Dalam penelitian ini teknik memainkan instrumen Perkusi yang digunakan adalah teknik percussion yaitu instrumen yang dipukul dengan ala pemukul (seperti stik), baik pada instrumen Perkusi ritmis (dalam hal ini Drum), maupun melodis (Marimba dan Timpani).

\section{METODE PENELITIAN}

Penelitian dilakukan di Jurusan Pendidikan Seni Musik FBS UNY pada bulan September s/d November 2007. Subjek dalam penelitian ini adalah mahasiswa semester I dan semester III kelas Reguler yang menempuh mata kuliah PIM Perkusi, masing-masing berjumlah 2 dan 3 orang. Dipilihnya kelas Reguler, karena walaupun jumlah mahasiswa yang menempuh mata kuliah tersebut dapa dikatakan ideal jika dibandingkan dengan kelas Non Reguler, namun dalam pelaksanaannya masih terdapat kendala-kendala sehingga prestasi belajar yang dicapai kurang optimal.

Metode yang digunakan dalam penelitian ini adalah Classroom Action Research (Penelitian Tindakan Kelas). Secara sederhana penelitian Action Research adalah "learning by doing", yaitu seorang peneliti mengidentifikasi masalah, kemudian melakukan suatu tindakan untuk memecahkan masalah, dan mengamati keberhasilan dari apa yang telah dilakukan. Selanjutnya, jika penelitian tersebut belum berhasil, maka suatu tindakan dapat diterapkan kembali. Oleh karena itu, dalam action research terdapat sebuah siklus sederhana, yang setiap siklusnya terdiri atas empat tahap, yaitu plan, act, observe, reflect (Brien, 1998:2).

Dalam penelitian ini jenis yang digunakan adalah participatory research. Hal ini dikarenakan adanya keterlibatan peneliti pada seluruh proses penelitian, sebagaimana yang dikemukakan oleh Harding, dkk melalui Madya (1994), bahwa dikatakan penelitian tindakan partisipan karena peneliti juga terlibat dalam proses penelitian dari awal hingga akhir. Adapun model yang digunakan adalah model yang telah dikembangkan oleh Kemmis \& Mc. Taggart.
Model yang dikembangkan tersebut merupakan pengembangan dari konsep dasar yang diperkenalkan oleh Kurt Lewin, dimana model yang diperkenalkan olehnya menjadi acuan pokok atau dasar dari adanya berbagai model penelitian tindakan yang lain, khususnya PTK. Selanjutnya menurut Kemmis \& Mc. Taggart (1990 : 14), model yang telah dikembangkan adalah komponen acting (tindakan) dengan observing (pengamatan) dijadikan sebagai satu kesatuan. Disatukannya kedua komponen tersebut disebabkan oleh adanya kenyataan bahwa antara implementasi acting dan observing merupakan dua kegiatan yang tidak terpisahkan. Artinya, kedua kegiatan haruslah dilakukan dalam satu kesatuan waktu, begitu berlangsungnya suatu tindakan begitu pula observasi juga harus dilaksanakan. Demikian pula halnya dalam penelitian ini, dimana tahap pengamatan dilakukan bersamaan dengan tahap tindakan. Untuk lebih tepatnya, gambaran komponen tersebut dapat dilihat pada desain berikut ini.

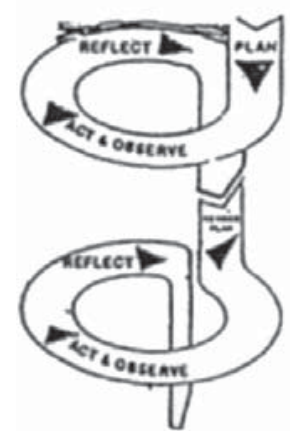

Gambar 1. Bentuk desain Penelitian Tindakan Kemmis \& Taggart

Adapun kegiatan penelitian yang dilakukan adalah sebagai berikut: 1) Merancang dan menyusun materi pembelajaran serta merancang tindakan yang akan dilakukan; 2) melakukan tindakan yang telah dirancang dan disusun dalam proses belajar mengajar praktik instrumen perkusi. Tindakan ini berupa mencatat dan merekam mahasiswa dalam praktik instrumen perkusi, antara lain teknik memegang stik, teknik memukul Drum, Marimba, dan Timpani, serta kontrol dalam tempo; 3) mengamati proses tindakan yang dilaksanakan; 4) Mengadakan evaluasi berdasarkan hasil refleksi.

Teknik pengumpulan data dilakukan dengan cara wawancara dan observasi. Wawancara dilakukan guna memperoleh pendapat para mahasiswa tentang efektivitas pemanfataan portofolio dalam pembelajaran praktik intrumen perkusi, sedangkan instrumen penelitian berupa 1) angket, digunakan untuk 
mengungkap pendapat mahasiswa dalam mengikuti perkuliahan PIM Perkusi; 2) lembar observasi, digunakan untuk mengamati proses pembelajaran praktik instrumen Perkusi; 3 ) tes, digunakan untuk mengetahui seberapa jauh penguasaan mahasiswa terhadap materi yang diberikan khususnya setelah diberikan tindakan, sehingga diharapkan tindakan yang telah diberikan tersebut dapat meningkatkan prestasi belajar mahasiswa dalam praktik instrumen Perkusi. Selanjutnya, data yang telah terkumpul dianalisis dengan menggunakan teknik deskriptif kuantitatif dan deskriptif kualitatif. Deskriptif digunakan untuk menyajikan data yang meliputi ukuran sentral (mean), dan deskriptif kualitatif yang digunakan untuk mendeskripsikan data dari hasil observasi dan wawancara.

\section{HASILDAN PEMBAHASAN}

Langkah awal yang dilakukan dalam penelitian ini adalah melakukan pembuatan rencana pembelajaran. Hal ini dilakukan agar dalam pelaksanaan pembelajaran dengan pemberian tindakan yang telah ditentukan dapat berjalan dengan lancar dan sesuai dengan tujuan yang ingin dicapai.

Adapun perencanaan tersebut yaitu menentukan materi-materi yang akan diberikan, baik pada mahasiswa semester I maupun pada mahasiswa semester III. Materi-materi tersebut meliputi ritme-ritme dasar, tangganada $\mathrm{C}$ mayor, dan $\mathrm{G}$ mayor pada mahasiswa semester I. Sementara itu, pada mahasiswa semester III, membahas materi berbagai macam ritme untuk memainkan pola irama Funk dengan teknik yang baik dan benar.

Selanjutnya menyiapkan setting pembelajaran sekaligus menyiapkan tindakan yang akan diberikan yaitu penggunaan portofolio. Penggunaan portofolio yang dilakukan berupa mencatat secara detail dan merekam kegiatan mahasiswa dalam praktik instrumen Perkusi.

\section{Pelaksanaan Siklus I}

Pada awal pertemuan siklus I, mahasiswa semester I memainkan ritmeritme dasar yaitu 1/4, dan 1/8 yang dikombinasi pada Hi-Hat, Snare Drum, dan Bass Drum. Ritme-ritme tersebut dimainkan dalam tempo lambat, kemudian ditingkatkan menjadi sedang. Setelah mahasiswa selesai melatih ritme 1/4 dan 1/8 pada drum, dilanjutkan dengan memainkan lagu Minuet karya W. A. Mozart dalam tangganada C, dan lagu Hunter's Chorus karya CM Von Weber dalam tangganada $\mathrm{G}$ pada marimba. Mahasiswa diberi kesempatan untuk latihan praktik perkusi dengan materi-materi yang telah ditentukan terlebih dahulu. Hal ini dilakukan agar mahasiswa benar-benar siap untuk dinilai.

Setelah mahasiswa siap untuk dinilai, maka penilaian baru dilakukan Materi-materi yang diberikan dibahas dalam tiga pertemuan dengan langkahlangkah sebagai berikut : a) mahasiswa memainkan ritme 1/4 dan 1/8 pada drum.
Pada saat mahasiswa memainkan ritme tersebut, ada saatnya terjadi tanya jawab dengan mahasiswa. Setelah selesai praktik pada drum, maka praktik dilanjutkan pada marimba (instrumen perkusi melodis) dengan memainkan lagu dalam tangganada Minuet karya W. A. Mozart dalam tangganada C, dan lagu Hunter's Chorus karya CM Von Weber dalam tangganada G. Seperti halnya saat praktik drum, pada bagian ini mahasiswa juga banyak bertanya tentang notasi dan ritmeritme yang dimainkan; b) setelah selesai memainkan materi-materi tersebut, dilakukan penilaian tahap awal, guna mengetahui hasil praktik mahasiswa dalam memainkan instrumen Perkusi; c) pada pertemuan berikutnya, mahasiswa memainkan kembali materi-materi yang menekankan ritme $1 / 4$ dan $1 / 8$, serta lagu Minuet karya W. A. Mozart dalam tangganada C, dan lagu Hunter's Chorus karya CM Von Weber dalam tangganada G. Disini, peneliti menggunakan portofolio yaitu mencatat dan merekam secara detail kemampuan mahasiswa dalam memainkan ritme $1 / 4$ dan $1 / 8$, serta mampu membaca notasi dan mampu memainkannya pada Marimba. Selain itu, teknik memegang stik, serta teknik memukul (termasuk penjarian). Pada semester I ini, jumlah mahasiswa yang mengikuti perkuliahan praktik Perkusi sebanyak 2 orang. Sementara itu, mahasiswa semester III memainkan berbagai macam ritme yang dikombinasi pada Hi-Hat, Snare Drum, Bass Drum, dan Tom-Tom. Latihan ini merupakan persiapan untuk memainkan irama Funk. Selain itu juga memainkan teknik "buka" dan "tutup" pada Hi-Hat.

Seperti halnya mahasiswa semester I, pada mahasiswa semester III juga diberi kesempatan untuk melatih materi-materi tersebut. Hal ini dilakukan agar mahasiswa mempunyai persiapan untuk dilakukan penilaian. Setelah benar-benar siap, maka penilaian baru dilakukan.

Adapun pelaksanaan pemberian materi dibagi dalam tiga pertemuan, dengan langkah-langkah sebagai berikut: a) mahasiswa memainkan ritme 1/16 pada drum, variasi ritme 1/4, 1/8, serta "off beat", dan open-close pada Hi-Hat. Kemudian dilanjutkan dengan memainkan kombinasi berbagai macam ritme pada Drum. Pada saat mahasiswa memainkan materi tersebut, ada saatnya terjadi tanya jawab dengan mahasiswa; b) setelah selesai memainkan materi-materi tersebut, dilakukan penilaian tahap awal, guna mengetahui hasil praktik mahasiswa dalam memainkan instrumen Perkusi; c) pada pertemuan berikutnya, mahasiswa memainkan kembali materi-materi berbagai macam ritme sebagai persiapan memainkan pola irama Funk. Disini, peneliti menggunakan portofolio yaitu mencatat dan merekam secara detail kemampuan mahasiswa dalam memainkan kombinasi berbagai macam ritme pada Drum dengan teknik yang baik dan benar. Pada semester III ini, jumlah mahasiswa yang mengikuti perkuliahan praktik Perkusi sebanyak 3 orang. 
Setelah mahasiswa baik semester I maupun semester III benar-benar telah siap untuk dinilai, maka penilaian selanjutnya baru dilakukan. Penilaian dilakukan untuk mengetahui apakah terdapat peningkatan keterampilan bermain instrumen perkusi sebelum dan sesudah menggunakan portofolio. Penilaian ini tidak hanya dilihat dari meningkatnya keterampilan bermain perkusi, tetapi juga adanya perubahan sikap dan perilaku mahasiswa, serta motivasi dan kemauan belajar dan berlatih praktik instrumen perkusi secara mandiri.

Setelah selesai pelaksanaan siklus I, dilakukan evaluasi. Evaluas dilaksanakan bertepatan dengan ujian tengah semester yang telah ditentukan. Pada ujian tengah semester ini, baik mahasiswa semester I maupun semester III memainkan materi-materi yang telah diberikan dengan teknik yang baik dan benar, namun kali ini dimainkan dengan tempo cepat dan mampu menginterpretasikannya. Adapun teknik-teknik tersebut meliputi cara memukul Drum, cara memegang stik, dan cara memukul Bass Drum dengan pedal. Berikut nilai praktik instrumen Perkusi sebelum dan setelah dilaksanakan siklus I pada mahasiswa semester I dan mahasiswa semester III.

Tabel 1. Nilai Praktik Instrumen Perkusi Mahasiswa Semester I Sebelum dan Sesudah Siklus

\begin{tabular}{|c|c|c|c|}
\hline \multirow{2}{*}{ No. } & \multirow{2}{*}{ IIM } & \multicolumn{2}{|c|}{ Nilai } \\
\cline { 3 - 4 } & & Sebelum Siklus I & Sesudah Siklus I \\
\hline 1. & 04208241035 & 65.5 & 68.0 \\
\hline 2. & 07208241018 & 58.5 & 60.5 \\
\hline & Mean = & $\mathbf{6 2 . 0}$ & $\mathbf{6 4 . 2 5}$ \\
\hline
\end{tabular}

Berdasarkan tabel 1, terlihat bahwa ada peningkatan nilai praktik instrumen Perkusi sebelum dan sesudah siklus I pada kedua mahasiswa. Hal in ditunjukkan dengan nilai mean yaitu 62,0 pada sebelum siklus I, dan 64,25 pada sesudah siklus I

Dengan demikian, dapat dikatakan bahwa nilai praktik bermain instrumen Perkusi kedua orang mahasiswa meningkat, namun belum menunjukkan hasi yang diharapkan. Hal ini dikarenakan mahasiswa tersebut belum benar-benar memahami ritme-ritme $1 / 4$ dan $1 / 8$, belum dapat membaca notasi balok dengan baik, dan belum bermain dengan teknik yang baik dan benar.

Adanya catatan-catatan dan rekaman saat mahasiswa berlatih dengan memainkan materi-materi tersebut, memberikan masukan pada mahasiswa tentang kekurangan dan kelebihan saat memainkan instrumen Perkusi. Namun demikian, mahasiswa kurang memperhatikan secara detail catatan dan rekaman yang ada, sehingga masih terdapat kekurangan dan kelemahan saat praktik Perkusi. Selanjutnya, pada tabel 2 dapat dilihat nilai praktik instrumen Perkusi mahasiswa semester III sebelum dan sesudah siklus I.
Tabel 2. Nilai Praktik Instrumen Perkusi Mahasiswa Semester III Sebelum dan Sesudah Siklus I

\begin{tabular}{|c|c|c|c|}
\hline \multirow{2}{*}{ No. } & \multirow{2}{*}{ NIM } & \multicolumn{2}{|c|}{ Nilai } \\
\cline { 3 - 4 } & & Sebelum Siklus I & Sesudah Siklus I \\
\hline 1. & 022824011 & 60.0 & 61.5 \\
\hline 2. & 04208241008 & 66.0 & 69.0 \\
\hline 3. & 06208241009 & 71.0 & 73.5 \\
\hline & Mean = & $\mathbf{6 5 . 6}$ & $\mathbf{6 8}$ \\
\hline
\end{tabular}

Berdasarkan tabel 2, dapat dilihat bahwa terdapat peningkatan nilai praktik instrumen Perkusi sebelum dan sesudah siklus I pada ketiga mahasiswa. tetapi belum menunjukkan hasil yang baik. Hal ini disebabkan masih adanya kelemahan mahasiswa dalam berlatih teknik, membaca notasi, dan memainkan ritme.

Penggunaan portofolio berupa catatan-catatan dan rekaman mahasiswa dalam berlatih dan praktik instrumen Perkusi dengan materi-materi yang telah disebutkan memberikan masukan pada mahasiswa tentang kekurangan dan kelebihannya. Dengan demikian, mahasiswa dapat memperbaiki kekurangankekurangan dan dapat meingkatkan kelebihannya dalam praktik instrumen Perkusi.

Berdasarkan hasil refleksi dan hasil evaluasi pada pelaksanaan siklus I dan diskusi peneliti dengan kolaborator, maka disepakati untuk diselenggarakan siklus II guna lebih meningkatkan proses dan hasil pembelajaran. Adapun dalam siklus ini, pada mahasiswa semester I penekanan materi difokuskan pada memainkan ritme sinkop pada snare drum dan bass drum, serta teknik bermain instrumen Perkusi, yaitu cara memukul, dan cara memegang stik baik stik untuk Drum maupun untuk Marimba, dan memainkan tangganada D dan A mayor. Sementara itu, pada semester III, materi difokuskan pada memainkan Fill Pattern yang terdiri atas 24 birama. Difokuskannya materi-materi tersebut adalah karena masih kurangnya mahasiswa pada semester I dalam menguasai teknik-teknik dasar bermain instrumen Perkusi dengan baik, sedangkan pada mahasiswa semester III, masih belum dapat bermain Fill Pattern dengan interpretasi yang baik.

Penggunaan Portofolio dilaksanakan kembali pada siklus II adalah untuk mendorong mahasiswa baik semester I maupun semester III agar lebih fokus dan termotivasi dalam mengikuti perkuliahan dan belajar praktik instrumen Perkusi, sehingga hasil keterampilan yang diperoleh dapat maksimal

\section{Pelaksanaan Siklus II}

Siklus II dilaksanakan pada tanggal 3 sampai dengan 20 November 2007 , dan diakhiri dengan tahap refleksi serta evaluasi, yaitu pada tanggal 27 November 2007. Penggunaan Portofolio diberikan kembali pada siklus II ini dimaksudkan 
agar mahasiswa lebih semangat, lebih fokus, dan lebih termotivasi dalam belajar praktik instrumen Perkusi.

Seperti halnya pada siklus I, pemberian materi pada mahasiswa semester I dilaksanakan dalam tiga pertemuan, dengan langkah-langkah sebagai berikut : 1) mahasiswa memainkan ritme sinkop pada drum, variasi ritme sinkop pada snare drum, dan pada bass drum. Kemudian dilanjutkan dengan memainkan kombinas berbagai macam ritme sinkop pada Drum. Setelah itu, mahasiswa memainkan lagu dalam tangganada D dan A mayor pada Marimba. Pada saat mahasiswa memainkan materi tersebut, ada saatnya terjadi tanya jawab dengan mahasiswa; 2) setelah selesai memainkan materi-materi tersebut, dilakukan penilaian tahap awal, guna mengetahui hasil praktik mahasiswa dalam memainkan instrumen Perkusi; 3) pada pertemuan berikutnya, mahasiswa memainkan kembali materi-materi berbagai variasi ritme sinkop baik pada snare drum maupun bass drum., serta lagu Ode to Joy karya L.V. Beethoven dalam tangganada D dan lagu The Stars and Stripes Forever karya John Philip Sousa dalam tangganada A mayor (pada Marimba). Disini, peneliti menggunakan portofolio yaitu mencatat dan merekam secara detail kemampuan mahasiswa dalam memainkan kombinasi berbagai macam ritme pada Drum dengan teknik yang baik dan benar.

Pada mahasiswa semester III, pemberian materi pada siklus II juga dilaksanakan dalam tiga pertemuan, dengan langkah-langkah sebagai berikut: 1) mahasiswa memainkan ritme $1 / 16$ pada drum, variasi ritme 1/4, 1/8, serta "off beat" , dan open-close pada Hi-Hat. Kemudian dilanjutkan dengan memainkan Fill Pattern yang terdiri atas 12 nomor. Pada saat mahasiswa memainkan mater tersebut, ada saatnya terjadi tanya jawab dengan mahasiswa; 2) setelah selesa memainkan materi-materi tersebut, dilakukan penilaian tahap awal, guna mengetahui hasil praktik mahasiswa dalam memainkan instrumen Perkusi; 3 pada pertemuan berikutnya, mahasiswa memainkan kembali materi-materi berbagai macam ritme dan Fill Pattern, sebagai persiapan memainkan pola irama Funk. Disini, peneliti menggunakan portofolio kembali yaitu mencatat dan merekam secara detail kemampuan mahasiswa dalam memainkan kombinasi berbagai macam ritme pada Drum dengan teknik yang baik dan benar.

Setelah mahasiswa baik semester I maupun semester III selesai melatih materi-materi yang diberikan, maka dilakukan penilaian kembali. Berikut dapat dilihat penilaian sebelum dan sesudah dilaksanakan siklus II.
Tabel 3 Nilai Praktik Instrumen Perkusi Mahasiswa Semester I Sebelum dan Sesudah Siklus II

\begin{tabular}{|c|c|c|c|}
\hline \multirow{2}{*}{ No. } & \multirow{2}{*}{ NIM } & \multicolumn{2}{|c|}{ Nilai } \\
\cline { 3 - 4 } & & Sebelum Siklus II & Sesudah Siklus II \\
\hline 1. & 04208241035 & 70 & 76,5 \\
\hline 2. & 07208241018 & 62,5 & 70 \\
\hline & Mean = & $\mathbf{6 6 . 2 5}$ & $\mathbf{7 3 . 2 5}$ \\
\hline
\end{tabular}

Berdasarkan tabel 3, terlihat bahwa terdapat peningkatan secara signifikan nilai praktik instrumen Perkusi sebelum dan sesudah siklus II pada kedua mahasiswa. Hal ini ditunjukkan dengan nilai mean yaitu 66,25 pada sebelum siklus II, dan 73,25 pada sesudah siklus II. Dengan demikian, dapat dikatakan bahwa penggunaan Portofolio dalam pembelajaran praktik instrumen Perkusi meningkatkan prestasi belajar mahasiswa. Selanjutnya, pada tabel 4 dapat dilihat nilai praktik instrumen Perkusi mahasiswa semester III sebelum dan sesudah siklus II.

Tabel 4. Nilai Praktik Instrumen Perkusi Mahasiswa Semester III Sebelum dan Sesudah Siklus II

\begin{tabular}{|c|c|c|c|}
\hline \multirow{2}{*}{ No. } & \multirow{2}{*}{ NIM } & \multicolumn{2}{|c|}{ Nilai } \\
\cline { 3 - 4 } & & Sebelum Siklus II & Sesudah Siklus II \\
\hline 1. & 022824011 & 63,5 & 71,5 \\
\hline 2. & 04208241008 & 68,5 & 74,0 \\
\hline 3. & 06208241009 & 74,0 & 78,0 \\
\hline & Mean = & $\mathbf{6 8 . 6}$ & $\mathbf{7 4 , 5}$ \\
\hline
\end{tabular}

Berdasarkan tabel 4, terlihat bahwa terdapat peningkatan nilai praktik instrumen Perkusi sebelum dan sesudah siklus II pada ketiga mahasiswa. Hal ini ditunjukkan dengan nilai mean yaitu 68,6 pada sebelum siklus II, dan 74,5 pada sesudah siklus II. Dengan demikian, dapat dikatakan bahwa penggunaan Portofolio dalam pembelajaran praktik instrumen Perkusi meningkatkan prestasi belajar mahasiswa.

Pada tahap refleksi, berdasarkan hasil observasi dan evaluasi terlihat adanya peningkatan keterampilan mahasiswa dalam bermain instrumen Perkusi secara signifikan. Selain itu, juga terlihat adanya perubahan sikap khususnya dalam hal tanggung jawab. Mahasiswa lebih fokus dan serius dalam berlatih dan menyelesaikan tugas-tugas yang diberikan.

Dengan adanya tindakan berupa penggunaan Portofolio, telah menghasilkan suatu perubahan sikap yang positif, antara lain mahasiswa lebih termotivasi dalam mengikuti perkuliahan khususnya dalam belajar praktik 
instrumen Perkusi, serta lebih rajin dan lebih rutin dalam berlatih, sehingga hal in berdampak pada meningkatnya prestasi belajar mahasiswa dalam praktik tersebut.

Berdasarkan hasil observasi, evaluasi dan refleksi, terlihat adanya peningkatan prestasi belajar. Tidak hanya itu saja, tetapi juga terlihat adanya perubahan sikap yang positif. Hal ini terjadi setelah dilakukan suatu upaya yaitu penggunaan Portofolio dalam pembelajaran tersebut yang berupa mencatat dan merekam hasil latihan praktik mahasiswa secara detail. Dengan dilakukannya pencatatan dan rekaman tersebut, mahasiswa lebih mengetahui kekurangan dan kelebihannya dalam praktik instrumen Perkusi, sehingga lebih termotivasi untuk memperbaiki kekurangan-kekurangan yang ada tersebut dan dapat meningkatkan kelebihan yang dimiliki. Dengan demikian, dapat dikatakan bahwa pemberian tindakan berupa penggunaan portofolio yaitu mencatat dan merekam, berhasil dengan baik dari segi kognitif, afektif, maupun psikomotor.

Dari segi kognitif, terlihat adanya peningkatan pemahaman mahasiswa baik semester I maupun semester III terhadap berbagai macam ritme, termasuk nilai ketukan yang terdapat di dalamnya. Selain itu, pada mahasiswa semester I, dapat memahami dengan baik beberapa tangganada, antara lain C, G, D, dan A mayor.

Dari segi afektif, terlihat adanya perubahan sikap yang positif pada mahasiswa antara lain lebih semangat, lebih termotivasi, dan lebih bertanggung jawab dalam mengikuti perkuliahan praktik instrumen Perkusi., serta lebih rajin dalam berlatih. Selanjutnya dari segi psikomotor, terlihat adanya peningkatan keterampilan pada mahasiswa dalam bermain instrumen Perkusi, baik ritmi maupun melodis. Dalam memainkan berbagai macam ritme, rata-rata seluruh mahasiswa ini dapat memainkannya dalam tempo cepat. Demikian pula, saat memainkan Marimba, serta Timpani.

Penggunaan Portofolio dalam perkuliahan praktik instrumen Perkusi akan terus digunakan guna menunjang keberhasilan pembelajaran tersebut. Hal in dilakukan berdasarkan hasil yang telah diperoleh melalui penelitian yang telah dilakukan, yaitu dengan penggunaan Portofolio tersebut memberikan dampak yang positif pada mahasiswa baik dari segi kognitif, afektif, maupun psikomotor.

\section{PENUTUP}

Pemanfataan portofolio dalam praktik instrumen Perkusi yang dilakukan berupa mencatat dan merekam secara detail kegiatan mahasiswa saat praktik instrumen tersebut terbukti dapat meningkatkan prestasi belajar khususnya keterampilan bermain instrumen Perkusi baik ritmis maupun melodi pada mahasiswa semester I maupun mahasiswa semester III yang menempuh perkuliahan tersebut.
Berdasarkan hasil evaluasi, keberhasilan ini tidak hanya dari segi psikomotor saja, tetapi juga dari segi kognitif maupun afektif. Dari segi kognitif, terlihat adanya peningkatan pemahaman mahasiswa baik semester I maupun semester III terhadap berbagai macam ritme, termasuk nilai ketukan yang terdapat di dalamnya. Selain itu, pada mahasiswa semester I, dapat memahami dengan baik beberapa tangganada, antara lain C, G, D, dan A mayor. Dari segi afektif, terlihat adanya perubahan sikap yang positif pada mahasiswa antara lain lebih semangat, lebih termotivasi, dan lebih bertanggung jawab dalam mengikuti perkuliahan praktik instrumen Perkusi, serta lebih rajin dalam berlatih.

\section{DAFTAR PUSTAKA}

Brien, R. 1998. An Overview of The Methodological Approach of Action Research. Diambil pada tanggal 17 Maret 2007, dari http://www.web.net/ robrien/ papers/arfinal.html.

Diagram, G. 1976. Musical Instrument of The World. Canada : Diagram Visual Information, Ltd.

Jones, Goerge Thaddeus. 1974. Music Theory. London : A Division of Harper \& Row Publishers.

Madya, S. 1994. Panduan Penelitian Tindakan. Yogyakarta: Lembaga Penelitian IKIPYogyakarta.

Mangkoesapoetra, A. Arief. 2007. Model Pembelajaran Portofolio : Sebuah Tinjauan Kritis. Diambil pada tanggal 15 April 2007, dari http://researchengines.com/0805arief3.html.

Sharp, E. J. 2000. Using Portfolios in The Classroom. Diambil pada tanggal 17 Maret 2007, dari http://fie.engrng.pitt.edu/fie97/papers/1427.pdf. 